\title{
Evaluation of the Anti-snake Venom Activity of Leaf Extract of Sansevieria liberica ger.\& labr (Agavaceae.) in Mice
}

\author{
Peter A. Akah ${ }^{1,2}$, Theresa S. Nwagu ${ }^{1}$, Martha N. Oforkansi ${ }^{2}$
}

\author{
${ }^{1}$ Department of Pharmacology and Toxicology, Faculty of Pharmaceutical Sciences, Nnamdi Azikiwe University, \\ Awka, Nigeria \\ ${ }^{2}$ Department of Pharmacology and Toxicology, Faculty of Pharmaceutical Sciences, University of Nigeria, Nsukka, \\ Nigeria
}

\begin{abstract}
The prevalence of snake bite and death from snake bite envenomation is becoming a serious public health problem globally. The cost, non availability and the adverse reactions associated with antisnake venom serum has favoured the use of medicinal herbs by traditional healers in the treatment of snakebites. In this study we evaluated the antisnake venom activity of the leaves of Sansevieria liberica against Naja naja nigricollis venom in mice. S. liberica is very popular among the traditional healers in south east Nigeria for the treatment of snake bites. The ground fresh leaves were extracted with ethanol and a portion of the ethanol extract was fractionated with $n$-hexane, ethyl acetate and butanol to afford the respective solvent fractions. The extract was subjected to acute toxicity $\left(\mathrm{LD}_{50}\right)$ and phytochemical testing. The $\mathrm{LD}_{50}$ of the venom was similarly determined, The antisnake venom activity of the extract/fraction was determined against the $\mathrm{LD}_{50}(353.5 \mathrm{ug} / \mathrm{kg})$ and double the $\mathrm{LD}_{50}(707 \mathrm{ug} / \mathrm{kg})$ of the venom. The effect of the extract on bleeding and clotting time of the venom-intoxicated mice was investigated. Also studied was the effect of the extract on acetylcholine-induced contraction of the isolated frog rectus abdominus. The extract/fractions significantly protected the mice from Naja naja nigricollis venom-induced mortality in mice. The bleeding and clotting time of the venom-intoxicated rats were significantly $(\mathrm{p}<0.05)$ decreased by the extract/fractions. The acetylcholine-induced contraction of frog rectus abdominus was significantly inhibited by the extract. These results suggest that the leaves of $S$. liberica exhibit antisnake venom properties that could be harnessed in treating patients with snakebite envenomation.
\end{abstract}

Keywords: Sansevieria liberica, Naja naja nigricollis, Bleeding Time, Clotting Time, Frog Rectus Abdominus

\section{Introduction}

Envenomation resulting from snake bites is an important public health problem in rural areas of tropical and sub- tropical countries of Africa, Asia, Oceania and Latin America (Chippaux 1998). It is a major socio-medical problem of south east Asia and sub-sahara African countries. About 216 species of snake occur in India alone, and about $25 \%$ of which is poisonous (Bawaskar, 2004). Poisonous snake species like Echis carinatus, Naja naja, Daboia russelli, Bungarus caeruleus and Ophiophagus hannah account for the majority of the bites and mortality (Gomes et al, 2010). The exact epidemiology as well as number of deaths from snake bites is difficult to obtain. This is partly due to the fact that most of the snake bites occur in the rural areas, and also the dependence on traditional healers. Snake venom is a very complex poison comprising a mixture of enzymatic and non-enzymatic toxic compounds and other non-toxic proteins, carbohydrates and metals. The poison components can incorporate proteases, nucleases, phosphodiesterases and other substances which alter cell functions and physiological processes (Sajon et al, 2017). The venom toxins are mainly neurotoxins, cytotoxins, myotoxins and cardiotoxins which evoke the variety of adverse reactions and death associated with snake venoms.

The treatment of snake bite varies as the bite and snake species. Antivenom immunotherapy remains the specific treatment against snake bite. In most poor resource countries where incidentally, snake bites are frequent, antivenoms are expensive and limited in supply. The mode of administration, usually parentrally, is another limitation. Most antivenoms are not broad spectrum, and their effectiveness may dependent on the type of snake involved and the time lag before administration. Antivenom therapy is associated with a number of side effects like anaphylactic shock, pyrogen reaction and serum sickness (Maya Devis et al, 2002).

The plant kingdom offers alternative option for the management of snake bites. Over the years many attempts have been made for the development of

This article is published under the terms of the Creative Commons Attribution License 4.0 Author(s) retain the copyright of this article. Publication rights with Alkhaer Publications.

Published at: http://www.ijsciences.com/pub/issue/2019-04/

DOI: 10.18483/ijSci.2012; Online ISSN: 2305-3925; Print ISSN: 2410-4477 
snake venom antidotes from plants sources. In most rural areas, traditional healers are the first port of call in cases of snake bite, and some of these cases were successfully treated with folk medicines, especially medicinal plants. Several medicinal plants, which appear in old drug recipes or which have been passed on by oral tradition, are believed to be snakebite antidotes and are recommended for the treatment of snake bite (Alam and Gomes, 2003; dos Santos Gomes et al, 2010; Kaushik et al, 2013). A number of medicinal plants including Jatropha species (Gomes et al, 2016; Felix-Silva et al, 2018), Asystasia gangetica (Enenebeaku et al, 2018), Parkia biglobosa (Asuzu and Harvey, 2003), Aloysia citriodora (Caceres et al, 2017), Sapindus saponaria (da Silva et al, 2012), Albizia lebbeek (Amog et al, 2016), Carissa spinarum (Janardhan et al, 2015), Piper longum (Shenoy et al, 2013) and Crinum jagus (Zadani et al, 2018) have been reported to possess antivenom properties.

In the eastern part of Nigeria, the leaves of Sansevieria liberica ger.\& labr is a common folk remedy for the treatment of snake bite, irrespective of the species of snake involved. Traditional healers in the area have attested to the usefulness and effectiveness of $S$. liberica leaves in the treatment of snake bite.

Sansevieria liberica belongs to the family Agavaceae. It is one of the bowstring hemp species and a pretty plant with bright green leaves growing 45 to $100 \mathrm{~cm}$ tall, with a smooth texture and light grey tip (Evans, 2005). The leaves are typically arranged in a rosette (Chahinian, 2005). It is known as "Moda" (Hausa), "Ebubagu" (Igbo) and "Ijoikoko" in (Yoruba) tribes of Nigeria. The common English name is Bow string hemp. The medicinal uses of $S$. liberica depend on the region. In the Northern part of Nigeria, it is used in traditional medicine to treat menorrhagia and menstrual pains, and to normalise abnormal menstrual period (Sambo and Ali, 2008). In the Western and Eastern parts of Nigeria it is used to treat diarrhoea, abdominal pains, gonorrhea, eczema, pile, snake bite, impotence, asthma, and high blood pressure (Odugbemi, 2008).

The anti-inflammatory (Ratheesh, 2007; Eze et al, 2011), anti-anaemic (Ikewuchi et al, 2010), sedative and anti-convulsant activities (Adeyemi et al, 2007) of the leaves and roots have been reported Also reported are the antidiarrhoeal (Adeyemi, et al, 2009), antihypertensive (Ikewuchi et al, 2011), analgesic (Umukoro et al, 2008), in vitro antitrypanosomal, antileishmanial and antiplasmodial (Bero et al, 2009, 2011), diuretic (Omodamiro and Jimoh, 2017) and anti-oxidant (Ikewuchi et al, 2013) activities.

To the best of our knowledge, there is no scientific report on the anti-snake venom potentials of $S$. liberica. The aim of this study was to evaluate the anti-snake venom activity of the leaves of the plant against Naja n.nigricollis venom in rodents.

\section{Materials And Methods \\ Collection and authentication of plant materials}

Fresh leaves of $S$. liberica were harvested from Ekwulobia in Aguata Local Government Area of Anambra State Nigeria and were identified $\mathrm{Mr}$. Patrick Ugwuozo of the Department of Botany, Nnamdi Azikiwe University, Awka Anambra State, Nigeria. Voucher specimen No. NAU 456 was deposited at the Herbarium of the Department of Pharmacognosy, Nnamdi Azikiwe University, Awka, Nigeria.

\section{Preparation of plant materials}

The methods used traditionally to prepare the plant materials which include powdering of the plant material followed by solvent (aqueous or organic) extraction was adopted. The fresh leaves were washed clean, cut into smaller pieces and pounded with a mortar and pestle. About $400 \mathrm{~g}$ of ground wet leaves was macerated with 2.5 litres of ethanol for 48 hours. The resulting solution was filtered using muslin cloth and concentrated under vacuum using rotary evaporator. The extract was further concentrated to dryness using water bath at $50{ }^{\circ} \mathrm{C}$ to yield $24.53 \mathrm{~g}(6.13 \%)$ of crude extract. Using solidliquid method of fractionation on a silica gel the crude extract was partitioned with $n$-hexane, ethyl acetate and butanol to obtain n-hexane (HF), ethyl acetate (EAF) and butanol (BF) fractions respectively in order of increasing polarity.

\section{Snake venom}

Freeze-dried venom of Naja. n. nigricollis was obtained from the Department of Veterinary Medicine, Ahmadu Bello University, Zaria, Kaduna State, Nigeria.

\section{Animals}

Albino mice of either sex (21-25 g) were used for the study. They were obtained from the Animal House of the Department of Pharmacology and Toxicology, Nnamdi Azikiwe University, Awka, Nigeria. The animals were housed in standard laboratory cages and conditions of $12 \mathrm{~h}$ light/dark cycle, at room temperature. Rodent feed (Guinea Feeds Nigeria Ltd) and clean water were provided ad libitum. All animal experiments was conducted in strict compliance with $\mathrm{NIH}$ guide for care and use of laboratory animals (National Institute of health (NIH) (2011) Pub No: 85-23).

\section{Phytochemical screening}

Qualitative phytochemical analysis of the extract was carried out to identify the presence of secondary metabolites using standard methods (Harborne, 1984) 

Mice

\section{Acute toxicity studies}

Acute toxicities $\left(\mathrm{LD}_{50}\right)$ of the extract (oral) and the snake venom (intraperitoneal) were determined using Lorke's method (Lorke, 1983).

\section{Anti snake venom activity}

The anti- snake venom activity of the crude extract and the fractions was tested in vivo against the $\mathrm{LD}_{50}$ $(353.5 \mathrm{ug} / \mathrm{kg})$ and double the $\mathrm{LD}_{50}(707 \mathrm{ug} / \mathrm{kg})$ of the snake venom. The extract and fractions were administered at the dose of 125,250 and $500 \mathrm{mg} / \mathrm{kg}$ orally. For this study, a total of 100 mice were used. The mice were divided into 4 groups (1-4). Group 1 served as the control, and received distilled water plus the two doses of the venom respectively. Groups 2-4 were used for immediate (concomitant), prophylaxis and curative treatments respectively. They were each subdivided into $6(n=5)$ and treated as follows:

\section{Group 1 ( control)}

1A: Distilled water $(5 \mathrm{ml} / \mathrm{kg})+$ venom $(353.5 \mathrm{ug} / \mathrm{kg})$. 1B: Distilled water $(5 \mathrm{ml} / \mathrm{kg})+$ venom $(707 \mathrm{ug} / \mathrm{kg})$.

Group 2. The venom was administered concomitantly with the extract.

2 A: Extract $(125 \mathrm{mg} / \mathrm{kg})+$ venom $(353.5 \mathrm{ug} / \mathrm{kg})$.

2 B: Extract $(250 \mathrm{mg} / \mathrm{kg})+$ venom $(353.5 \mathrm{ug} / \mathrm{kg})$

2C: Extract $(500 \mathrm{mg} / \mathrm{kg})+$ venom $(353.5 \mathrm{ug} / \mathrm{kg})$.

2D: Extract $(125 \mathrm{mg} / \mathrm{kg})+$ venom $(707 \mathrm{ug} / \mathrm{kg})$.

2E: Extract $(250 \mathrm{mg} / \mathrm{kg})+$ venom $(707 \mathrm{ug} / \mathrm{kg})$.

$2 \mathrm{~F}$ : Extract $(500 \mathrm{mg} / \mathrm{kg})+$ venom $(707 \mathrm{ug} / \mathrm{kg})$.

Group 3. The venom was administered 1 hour after the extract (Prophylaxix)

3A: Extract $(125 \mathrm{mg} / \mathrm{kg})+$ venom $(353.5 \mathrm{ug} / \mathrm{kg})$.

3B: Extract $(250 \mathrm{mg} / \mathrm{kg})+$ venom $(353.5 \mathrm{ug} / \mathrm{kg})$.

$3 C$ : Extract $(500 \mathrm{mg} / \mathrm{kg})+$ venom $(353.5 \mathrm{ug} / \mathrm{kg})$.

3D: Extract $(125 \mathrm{mg} / \mathrm{kg})+$ venom $(707 \mathrm{ug} / \mathrm{kg})$.

3E: Extract $(250 \mathrm{mg} / \mathrm{kg})+$ venom $(707 \mathrm{ug} / \mathrm{kg})$.

$3 F$ : Extract $(500 \mathrm{mg} / \mathrm{kg})+$ venom $(707 \mathrm{ug} / \mathrm{kg})$.

Group 4. The extract was administered 30 minutes after the venom.

4A: Venom $(353.5 \mathrm{ug} / \mathrm{kg})+$ extract $(125 \mathrm{mg} / \mathrm{kg})$. 4B: Venom $(353.5 \mathrm{ug} / \mathrm{kg})+$ extract $(250 \mathrm{mg} / \mathrm{kg})$. 4C: Venom $(353.5 \mathrm{ug} / \mathrm{kg})+$ extract $(500 \mathrm{mg} / \mathrm{kg})$. 4D: Venom $(707 \mathrm{ug} / \mathrm{kg})+$ extract $(125 \mathrm{mg} / \mathrm{kg})$. 4E: Venom $(707 \mathrm{ug} / \mathrm{kg})+$ extract $(250 \mathrm{mg} / \mathrm{kg})$. 4F: Venom $(707 \mathrm{ug} / \mathrm{kg})+$ extract $(500 \mathrm{mg} / \mathrm{kg})$.

\section{Anti snake venom activity of the fractions}

The fractions $(125 \mathrm{mg} / \mathrm{kg} \mathrm{p}$ o) and the venom (707 $\mathrm{ug} / \mathrm{kg}$ ip) were administered immediately (concurrently). The animals were observed for mortality for 24 hours.

\section{Evaluation of bleeding}

Twenty five (25) adult albino mice grouped into five $(n=5)$ were used for the study. Group 1 received distilled water and severed as the control. Group 2 had the venom $(707 \mathrm{ug} / \mathrm{kg})$ alone, while groups 3-5 received the venom and the extract 125, 250 and 500 $\mathrm{mg} / \mathrm{kg}$ respectively. The bleeding time was measured using the method of Mohammed et al (1969). Two hours after administering the venom $(707 \mathrm{ug} / \mathrm{kg})$, and treatment with the extract, pressure was built at the tail of the animal by stroking it with fingers. Then a sterile needle was used to puncture one of the blood vessels lying alongside of the tail. The blood that oozed out of the site was blotted gently but completely with filter paper every 15 seconds until bleeding ceases. The time of the first appearance of blood and stopping of the blood flow was taken as the bleeding time.

\section{Evaluation of clotting time}

This study involved twenty five (25) adult albino mice grouped into five $(n=5)$. Group 1 received distilled water and severed as the control. Group 2 had the venom $(707 \mathrm{ug} / \mathrm{kg})$ alone, while groups 3-5 received the venom and the extract 125, 250 and 500 $\mathrm{mg} / \mathrm{kg}$ respectively.

The clotting time was evaluated using capillary coagulation method. Non-heparinized capillary tube was used to collect blood from the retro-orbital plexus of the animal through capillary action until whole length of the tube was filled with blood. At 15 seconds interval, one half of the capillary tube was carefully broken off at one end and gently pulled apart to look for the fill in thread which is an indication of clotting. The breaking of the tube was done at $15 \mathrm{sec}$ interval until fibrin thread was seen. The time it took the thread to form is taken as the clotting time (Igboechi and Anuforo, 1986).

\section{Invitro study}

\section{Effect on frog rectus abdominus}

Adult frog were killed and cut open. The rectus abdominus was obtained and mounted in an organ bath containing Frog Ringer solution of the following composition gram/litre $\mathrm{NaCl}$ (6.0), $\mathrm{KCl}$ (0.075), $\mathrm{CaCl}_{2}(0.100), \mathrm{NaHCO}_{3}(0.100)$ and aerated with air and maintained at room temperature. The resting tension on the tissue was $1.5 \mathrm{~g}$. The tissue was equilibrated for 30 minutes before graded responses to acetylcholine were obtained Responses to the submaximum concentration of Ach were re-established in the pressure of 10 and $20 \mathrm{mg}$ of the extract after 15 minutes incubation. The responses were recorded on Unirecorder 7050 (Ugo Basile, Italy) through an isotonic Transducer, 7004 (Ugo Basile, Italy).

\section{Statistical analysis}

Results were presented as mean \pm Standard error of mean (SEM). Data were subjected to one way analyses of variance (ANOVA) followed by Post-hoc Turkey's test for multiple comparison. Statistical package for social science (SPSS-20) was used for data analyses.

$\mathrm{P}<0.05$ was considered to be statistically significant. 
Evaluation of the Anti-snake Venom Activity of Leaf Extract of Sansevieria liberica ger.\& labr (Agavaceae.) in Mice

\section{Results}

Phytochemical constituents

Qualitative phytochemical analysis revealed the presence of saponins, flavonoids and terpenoids in

Table 1: Phytochemistry of ethanol leaves extract of Sansivieria liberica

\begin{tabular}{|l|l|}
\hline Phytochemical constituents & Amount \\
\hline Alkaloids & + \\
\hline Saponins & ++ \\
\hline Tannins & - \\
\hline Flavonoids & ++ \\
\hline Steroids & + \\
\hline Terpenoids & ++ \\
\hline Cardiac Glycosides & + \\
\hline Proteins & - \\
\hline Carbohydrates & - \\
\hline
\end{tabular}

(+) present in small concentration, (++) present in high concentration, (-) absent

\section{Acute toxicity test}

high amounts while alkaloids, steroids and cardiac glycosides occurred in smaller amount quantities (Table 1).

The acute toxicity test indicated that the $\mathrm{LD}_{50}$ of the extract was above $5000 \mathrm{mg} / \mathrm{kg}$, while that of the snake venom was $353.55 \mathrm{ug} / \mathrm{kg}$.

Effect of the extract on $L_{50}$ of the snake venom

On simultaneous administration of the extract with the venom, $100 \%$ protection was afforded by 125 and $250 \mathrm{mg} / \mathrm{kg}$ of the extract (Table 2).

In prophylactic studies, all the mice survived at the doses of 125 and $250 \mathrm{mg} / \mathrm{kg}$ of the extract. However $80 \%$ protection was recorded at $500 \mathrm{mg} / \mathrm{kg}$ dose (Table 2).

When the extract was administered thirty minutes after exposure of animals to the $\mathrm{LD}_{50}$ dose of the snake venom, all the animals treated with $125 \mathrm{mg} / \mathrm{kg}$ of the extract were protected while $80 \%$ protection was recorded at 250 and $500 \mathrm{mg} / \mathrm{kg}$ doses (Table 2).

Table 2. Effect of the extract on the $\mathrm{LD}_{50}$ of the snake venom

\begin{tabular}{|c|c|c|c|c|}
\hline Treatment & Dose (mg/kg) & No of animals & Mortality & \% survival \\
\hline $\begin{array}{l}\text { Control (distilled } \\
\text { water) }\end{array}$ & $5 \mathrm{ml} / \mathrm{kg}$ & 5 & 3 & 40 \\
\hline \multicolumn{5}{|l|}{ Concomitant } \\
\hline \multirow[t]{3}{*}{ Extract } & 125 & 5 & 0 & 100 \\
\hline & 250 & 5 & 0 & 100 \\
\hline & 500 & 5 & 1 & 80 \\
\hline \multicolumn{5}{|l|}{ Prophylaxis } \\
\hline \multirow[t]{3}{*}{ Extract } & 125 & 5 & 0 & 100 \\
\hline & 250 & 5 & 0 & 100 \\
\hline & 500 & 5 & 0 & 100 \\
\hline \multicolumn{5}{|c|}{30 minutes after administration of snake venom } \\
\hline \multirow[t]{3}{*}{ Extract } & 125 & 5 & 0 & 100 \\
\hline & 250 & 5 & 1 & 80 \\
\hline & 500 & 5 & 1 & 80 \\
\hline
\end{tabular}

Effect of the extract on double $\mathrm{LD}_{50}(707 \mathrm{ug} / \mathrm{kg})$ of the snake venom:

The effect of extract on the double $\mathrm{LD}_{50}$ of the venom is shown in Table 3. The extract was more effective prophylactically as all the mice survived at all the 3 doses of the extract tested,
When the extract was administered thirty minutes after exposure of the animals to twice the $\mathrm{LD}_{50}$ of the snake venom, the percent protection was dose dependent (Table 3). 
Evaluation of the Anti-snake Venom Activity of Leaf Extract of Sansevieria liberica ger.\& labr (Agavaceae.) in Mice

Table 3. Effect of the extracts on double $\mathrm{LD}_{50}(707 \mathrm{ug} / \mathrm{kg})$ of the snake venom

\begin{tabular}{|c|c|c|c|c|c|}
\hline Treatment & Doses (mg/kg) & No of animals & No of Death & Survival & \% survival \\
\hline $\begin{array}{l}\text { Control (distilled } \\
\text { water) }\end{array}$ & $5 \mathrm{ml} / \mathrm{kg}$ & 5 & 5 & 0 & 0 \\
\hline \multicolumn{6}{|l|}{ Concomitant } \\
\hline \multirow[t]{3}{*}{ Extract } & 125 & 5 & 0 & 5 & 60 \\
\hline & 250 & 5 & 1 & 4 & 80 \\
\hline & 500 & 5 & 1 & 4 & 80 \\
\hline \multicolumn{6}{|l|}{ Prophylaxis } \\
\hline \multirow[t]{3}{*}{ Extract } & 125 & 5 & 0 & 5 & 100 \\
\hline & 250 & 5 & 0 & 5 & 100 \\
\hline & 500 & 5 & 0 & 5 & 100 \\
\hline \multicolumn{6}{|c|}{30 minutes after administration of snake venom } \\
\hline \multirow[t]{3}{*}{ Extract } & 125 & 5 & 3 & 2 & 40 \\
\hline & 250 & 5 & 2 & 3 & 60 \\
\hline & 500 & 5 & 0 & 5 & 100 \\
\hline
\end{tabular}

Anti-snake venom effect of the fraction

The ethyl acetate fraction $(125 \mathrm{mg} / \mathrm{kg}$ ) protected $100 \%$ of the animals from the $707 \mathrm{ug} / \mathrm{kg}$ dose of the venom while the $n$-hexane and butanol fractions at the same dose afforded 60 and $40 \%$ protection respectively. (Table 4).

Table 4. Effect of the fractions on snake venom

\begin{tabular}{|l|l|c|c|c|c|}
\hline Treatments & Dose mg/kg & No of animals & No of death & Survival & \% Protection \\
\hline Control (distilled water) & $5 \mathrm{ml} / \mathrm{kg}$ & 5 & $5 / 5$ & $0 / 5$ & 0 \\
\hline n-hexane fraction & 125 & 5 & $2 / 5$ & $3 / 5$ & 60 \\
\hline Ethyl acetate fraction & 125 & 5 & $0 / 5$ & $5 / 5$ & 100 \\
\hline Butanol fraction & 125 & 5 & $3 / 5$ & $2 / 5$ & 40 \\
\hline
\end{tabular}

Effect of the extract on bleeding time.

There was a significant ( $p<0.05$ ) and dose-dependent reduction in the venom-induced haemorrhage in mice. (Table 5).

Table 5. Effect of the extract on bleeding time.

\begin{tabular}{|l|c|}
\hline Treatment & $\begin{array}{l}\text { Bleeding time } \\
\text { (sec) }\end{array}$ \\
\hline $\begin{array}{l}\text { Control, (Distilled water 5 } \\
\mathrm{ml} / \mathrm{kg})\end{array}$ & $1.1 \pm 0.14$ \\
\hline $\begin{array}{l}\text { Snake venom (707 ug/kg) } \\
\text { alone }\end{array}$ & $2.2 \pm 0.08$ \\
\hline Extract $125 \mathrm{mg} / \mathrm{kg}$ & $1.0 \pm 0.14^{*}$ \\
\hline Extract $250 \mathrm{mg} / \mathrm{kg}$ & $0.8 \pm 0.27^{*}$ \\
\hline Extract $500 \mathrm{mg} / \mathrm{kg}$ & $0.5 \pm 0.06^{*}$ \\
\hline
\end{tabular}

Values are presented as mean \pm Standard error of mean (SEM), $\mathrm{n}=5$. $* \mathrm{P}<0.05$
Effect of the extract on clotting time

The venom-induced increase in clotting time was significantly $(\mathrm{p}<0.05)$ and dose dependently decreased by the extract (Table 6).

Table 6: Effect of the wet extract on clotting time.

\begin{tabular}{|l|c|}
\hline Treatment & $\begin{array}{l}\text { Clotting time } \\
(\mathbf{s e c})\end{array}$ \\
\hline $\begin{array}{l}\text { Control, (Distilled water } \\
5 \mathrm{ml} / \mathrm{kg})\end{array}$ & $1.31 \pm 0.14$ \\
\hline Snake venom $(707 \mathrm{ug} / \mathrm{kg})$ alone & $2.60 \pm 0.9$ \\
\hline Extract $125 \mathrm{mg} / \mathrm{kg}$ & $1.43 \pm 0.12^{*}$ \\
\hline Extract $250 \mathrm{mg} / \mathrm{kg}$ & $1.08 \pm 0.06^{*}$ \\
\hline Extract $500 \mathrm{mg} / \mathrm{kg}$ & $0.84 \pm 0.17^{*}$ \\
\hline
\end{tabular}

Values are presented as mean \pm Standard error of mean $(\mathrm{SEM}), \mathrm{n}=5$. $* \mathrm{P}<0.05$ : 


\section{Effect of the extracts on acetylcholine induced contraction of the frog rectus abdominus}

The sub-maximum response induced by acetylcholine was reduced to 80 and $100 \%$ by 10 and $20 \mathrm{mg}$ of the extract respectively (data not shown)

\section{Discussion}

The adverse reactions associated with antisnake serum (Morais and Massaldi, 2009) have necessitated the search for alternatives for snake bite therapy. Serious attention has been shifted to herbal remedies mainly due to the acclaimed successes by the traditional healers in the management of snake bites with herbs. In this modern time, many locals still rely on the use of medicinal plants by traditional healers for the treatment of snake bites. A good number of plants have been reported to show good potentials for the treatment of snake bites (Mors, 1991., Gomes et al., 2010), and many procedures are been used to investigate plants with antisnake bite activity (Harvey, 2003, Adazu, et al 2005, Ode and Asuzu, 2006, da Silva et al 2012, Felix-Silva et al 2014). In view of the high cost of conventional anti-venoms and the significant percentage of patients who react adversely to them (Corrigan et al, 1978; Boyer et al, 2001), a systematic investigation of plant-based remedies for snake bite is justified.

In this study we investigated the leaves of Sansevieria liberica for antisnake venom activity. The results showed the ethanol extract of the leaves as a good candidate for treating snake bites. The result of the phytochemical screening of the extracts indicated the presence of some secondary metabolites that have been reported to have antisnake venom actions. Selvanayagam et al (1996) reported that many phytochemical constituents like flavonoids, quinonoids, xanthene, terpenoids and polyphenol possess protein binding and enzyme inhibiting properties and also inhibit snake venom phospholipase A2 (PLA2) activities of both viper and cobra venom. Chatterjee et al (2006) reported that lupeol acetate (an alkaloid) isolated from the root extracts of Indian Sarsaparilla hemidesmas indicus neutralized the lethality, haemorrhagenation, edema and phospholipase A2 (PLA2) effects induced by Doboia kauthia venom. Furthermore, triterpenoid present in $V$. negunda and $E$. officinalis were reported to be involved in venom inactivation processes and pentacyclic triterpenes are found widely in several anti-snake venom plants such as Aegle marmelos, Centipeda minima, Aloe vera, Phyllanthus niruri, Alstonia scholaris, Phyllanthus emblica, Elephentopus scaber, etc. (Mors et al, 2000). The effective venom neutralizing effect of Pioer longum fruit against Russell 's viper venom was attributed to the presence of piperine (Shenoy et al, 2013). The high flavonoids and alkaloids contents of the extract may partly contribute to the anti-venom activity of the extract, since they have been reported to possess protein binding and enzyme inhibiting properties, and also inhibit snake venom phospholipase A2 (PLA2) activity (Santosh et al, 2004).

Most snake venoms cause local and systemic bleeding which is the consequence of the damage to blood vessel walls by venom components. Therefore the ability of the extract to prevent the venominduced hemorrhagic activity may contribute to its anti-venom activity. Similar results have been reported for Hemidesmus indicus (Alam et al, 1994), Vitex negundo and Emblica officinalis (Alam et al, 2003), and Cclipta prostrate (Pithaynnkul et al, 2004).

The more potent anti-snake venom activity demonstrated by the ethylacetate fraction is indicative of the presence of more bioactive secondary metabolites in the fraction as ethylacetate has been reported by various authors to be an efficient solvent having the ability to scavenge both polar and nonpolar bioactive secondary metabolites especially alkaloids, flavonoids and saponins (Santosh et al, 2004). The ability of the extract to block acetylcholine-induced contraction of the skeletal muscle (Frog Rectus Abdominus) may be useful in ameliorating the venom-induced myotoxicity.

The results of this study indicate that the leaves of Sansevieria liberica contain pharmacologically active compounds that could be effective in treating patients with snakebite envenomation.

\section{References}

1. Adeyemi O.O, Yemitan .O.K, Adebisi .O.O. (2007). Sedative and anticonvulsant activities of the aqueous root extract Sanseviera liberica. Journal of Ethnopharmacology 113 (2):111-4.

2. Adeyemi O. O, Akindele A. J, and Ogunleye E. A. (2009). "Evaluation of the antidiarrheal effect of Sanseviera liberica root extract," Journal of Ethnopharmacology 123 (3): 459463.

3. Adzu B, Abubakar M. S, Izebe K. S, Akumka D. D and Gamaniel K. S (2005). Effect of Annona senegalensis root bark extracts on Naja nigricollis venom in rats. Journal of Ethnopharmacology 96: 507-513

4. Alam M.I., Auddy, B., Gomes, A. (1994.). Isolation purification and partial characterization of Viper venom neutralizing factor from the root extract of Indian medicinal plant Hemidesmus indicus R. British Toxicon. 32: 155-1557.

5. Alam M.I and Gomes A (2003). Snake venom neutralization by Indian medicinal plants (Vitex negundo and Emblica officinalis) root extracts. Journal of Ethnopharmacology 86 (3): $75-80$

6. Amog P. U, Manjuprasaanna V. N, Yariswamy A. N, Nanjaraj a. N et al (2016). Albizia lebbeckI seed metnanolic extract as complimentary therapy to manage local toxicity of Echis carinatus venom in murine model. Pharmaceutical Biology 54 (11): 2568-2574.

7. Azusu I. U and Harvey A. L (2003). The antisnake venom activities of Parkia biglobosa (Mimosaceae) stem bark extract. Toxicon 42(7): 763-768 
8. Bawaskar H.S (2004). Snake venoms and anti-venoms: critical supply issues. Journal of Association of Physicians India. 52 (2): 11-13.

9. Bero .J, Ganfon .H, Jonville .M.C, Michel .F, Fernand .G, Patrick .D, Mansourou .M, Joelle Q.L (2009). In vitro antiplasmodia activity of plants used in Benin in traditional medicine to treat malaria, . Journal of Ethnopharmacology 122 (3): 439-444

10. Bero J., Hannaert .V, Chataigné .G, Hérent .M.F, QuetinLeclercq J. (2011). In vitro antitrypanosomal and antileishmanial activity of plants used in Benin in traditional medicine and bio-guided fractionation of the most active extract. Journal of Ethnopharmacology 137(2): 998-1002. doi: 10.1016/j.jep.2011.07.022.

11. Boyer L.V, Seifert S.A, and Cain J.S (2001). Recurrence phenomena after immunoglobulin therapy for snake envenomations-part 2. Guidelines for clinical management with crotaline Fab antivenom. Annals of Emergency Medicine 37 (2): 196-20.

12. Caceres M. I, Recciardi G. A, Torres A. M, Ricciardi B. V et al (2017). In vitro antisnake venom activities of Aloysia citriodora, Palau: New possibilities for a known aromatic plant. Journal of Essential Oil Bearing Plants 20 (1): 132140.

13. Chahinian B.J (2005). The Splendid Sansevieria: An Account of the Species.ISBN 987-43-9250-9.

14. Chatterjee I, Chakravarty A.K., and Gomes .A (2006). Daboia russellii and Naja kaouthia venom neutralization by lupeol acetate isolated from the root extract of Indian sarsaparilla Hemidesmus indicus $R$. Journal of Ethnopharmacology. 106: 38-43

15. Chippaux J.P (1998). Snake Bite: Appraisal of the Global Situation. WHO Bulletin 76 (10):515-524

16. Corrigan .P, Russell F.E, and Wainschel .J (1978). "Clinical reactions to antivenom," in Toxicon-Animal, Plant and Microbial, P. Rosenberg, Ed., 457-465, Pergamon Press, Oxford, UK

17. Da Silva M. L, Mareussi S, Fernandes R. S, Pereira P. S et al (2012). Antisnake venom activities of extracts and fractions from callus cultures of Sapindus saponaria. Pharmaceutical Biology 50 (3): 366-375.

18. dos Ssanto Gomes J. A, Felix-Silva J, Fernandes M. J, Amaral J. G et al (2016). Aqueous leaf extract of Jatropha mollissima (Pohl) Bail decreases local effects induced by Bothropic venom. BioMed Reseach International 2016.DOI:10.1155/2016/6101742

19. Enenebeaku C. K, Umerie S. C, Nwankwo M. U and Enenebeaku C. K (2018). Antisnake venom activities of the leaf extracts of Asystasia gangetica and Newbouldia leavis (p. Beauv). Would News of Natural Sciences 16: 38-41

20. Eze, C. C, Inya-agha, S. I, Ezugwu, C. O, Ezea, S. C. (2011). Evaluation of anti- inflammatory property of the leaves of Sansevieria liberica, Asian PacificJournal of Tropical Medicine 4(10):791-795.doi:10.1016/S1995-7645 (11)60195-8

21. Evans .W.C (2005): A taxonomic approach to the study of medicinal plants and animal-derived drugs. In: Evans WC (ed.): Trease and Evans pharmacognosy, 5th ed. (15-40). India: Elsevier

22. Felix-Silva J, Souza T, Menezes Y. A. S, Cabral B et al (2014). Aqueous leaf extract of Jatropha gossypiifolia L.
(Euphorbiaceae) inhibits enzymatic and biological actions of Bothrops jararaca venom. PLOS ONE 9 (8) e104952.

23. Felix-Silva J, Gomes J. A. S, Fernandes J. M, Moura A. K. C et al (2018). Comparison of two Jatropha species (Euphorbiaceae) used popularly to treat snake bites in Brazil: Chemical profile, inhibitory activity against Bethrops erythromelas venom and antibacterial activity. Journal of Ethnopharmacology 213: 12-20

24. Gomes A, Das R, Sarkhel S, Mishra R (2010). Herbs and herbal constituents against snake bite. Indian Journal of Experimental Biology 48: 865-878.

25. Harborne J. B (1984). Phytochemical Methods: A Guide to Modern Technique of Plant Analyssis, $2^{\text {nd }}$ Edn. Chapman and Hall London, P 282.

26. Harvey A (2003). Testing of natural remedies for natura toxins. Toxicon 41:939.

27. Igboechi, A, C and Anuforo, D. C (1986). Anticoagulant activities of extracts of Epatorium odoratum and Vernonia amygdalina. In Sofowora A (Ed). The State of Medicinal Plants Research in Nigeria. University of Ile-Ife Press, Nigeria

28. Ikewuchi CC, Ikewuchi JC, Onyeike EN and Ayalogu EO (2010). Effect of Sansevieria liberica Gérôme and Labroy on plasma chemistry and haematological indices of saltloaded rats. Research Journal of Science and Technology. 2(5): $110-114$

29. Ikewuchi C.C, Ayalogu, E. O, Onyeka, E, N, Ikewuchi J.C (2011). Effect of aqueous extract of the leaves of Sansevieria liberica on blood pressure and pulse rate of sub-chronic salt loaded rats. Journal of Natural Remedies 11(2): 30-38

30. Ikewuchi C.J (2013). Positive moderation of the hematology, plasma biochemistry and ocular indices of oxidative stress in alloxan- induced diabetic rats, by an aqueous extract of the leaves of sansevieria liberica. Asian Pacific Journal of Tropical Medicine 11 (8 ): 467-472.

31. Janardhan B, Shrikanth V. M, Mirajkar K. K, Mores S. S (2015). In vitro antisnake venom properties of Carisa spinarum Linn leaf extracts. Journal of Herbs, Spices and Medicinal Plants 21 (3): 283-293.

32. Kaushik, A, Ambesajir, A, Kaushik, J. I and Girmay B (2013). Snake venom neutralization effects of African medicinal plants and their impact on snakebites: A Review. Asian Journal of Biomedical and Pharmaceutical Sciences 3(1): 1-6

33. Lorke D (1983). A new approach to practical acute toxicity testing. Archives of Toxicology 54(4): 275-287.

34. Maya Devi C, Vasantha B.M, Vijayan L. Umashankar P.R et al (2002). An improved method for isolation of anti-viper venom antibodies from chicken egg yolk. Journal of Biochemical and Biophysics Methods. 51(4): 129-138.

35. Mohammed, A. H, Serougi, M. S, and Hanna, M. M (1969)/ Observations on the effects of Echis carinatus venom on blood clotting. Toxicon 6: 215-219.

36. Mors W. B (1991). Plants active against snake bite. Plants and Traditional Medicine 5: 353-373.

37. Mors, W.B. (1991). Plants active against snake bite. In Wagner, H., Farnsworth, N.R. (Eds.), Economic and Medicinal Plant Research. 5: 353-373.

38. Morais V. M and Massaldi H (2009). Snake antivenom: Adverse reactions and production technology. Journal of Venom and Animal Toxins Including Tropical Diseases 15: 2-18. 
39. Mors, W.B., do Nascimento, M.C., Pereira, B.M.R., Pereira, N.A (2000). Plant natural products active against snake bitethe molecular approach. Phytochemistry. 55: 627-642.

40. Ode O. J and Azusu I. U (2006). The anti-snake venom activities of the mehtanolic extract of the bulb of Crinum jagus (maryllidaceae). Toxicon 48:331

41. Odugbemi .T (2008). A Textbook of Medicinal Plants in Nigeria. 1stEdition, University of Lagos Press, Nigeria.345395.

42. Omodamiro O. O and Jimoh M. A (2017). Evaluation of in vitro anti-oxidant, anti-inflammatory and diuretic potentials of Sansevieria liberica leaves in Wistar albino rats. The Pharmaceutical and Chemical Journal 4 (1): 16-24.

43. Pithayanukul P, Sasitorn L., Rapepol B, Narumol P, Rutt S (2004). Anti-venom potential of butanolic extract of Eclipta prostrate against Malayan pit viper venom. Journal of Ethnopharmacology. 90:347-352.

44. Ratheesh M. A (2007). Antiinflammatory activity of Sansevieria liberica on carrageenan-induced paw oedema in male rats. African Journal of Biotechnology 6 (10): 12091211.

45. Sajon S. R, Sana S and Rana S (2017). Anti-venoms for snake bite: A synthetic and traditional drugs review. Journal of Pharmacognosy and Phytochemistry 6 (3): 190-197
46. Sambo .B.Z, Ali .H.A, (2008). Some Medicinal Plants used as Traditional Recipes for some Disorders among Northern Communities in Nigeria. $1^{\text {st }}$ Edition, University of Lagos Press, 65.

47. Santosh R, Faltepur Sluvaji, Gawade P (2004). Preliminary screening of herbal plant extacts for anti-venom activity against common seen snake (Enhydrina schistose) Poisoning Parmacognosy Magazine 16: 56-60.

48. Selvanayagam, Z.E., Gnanavendhan, S.G., Balakrishna, K., Rao, R.B., Sivaraman, J., Subramanian, K., Puri, R., Puri, R.K. (1996). Ehretianone, a novel quinonoid xanthene from Ehretia buxifolia with antisnake venom activity. Journal of Natural Products. 59: 664-667.

49. Shenoy P. A, Nipate S. S, Sonpetkat J. M, Salvi N et al (2013). Antisnake venom activities of ethanol extract of Piper longum (Piperaceae) against Russell's viper venom: Characterization of piperine as acting principle. Journal of Ethnopharmacology 147 (2). DOI:10.1016/j.jep 102303.022

50. Umukoro .S and Ashorobi .R. B., (2008). Effects of the methanol leaf extract of Sansevieria liberica on the central nervous system in mice. Journal of Natural Remedies, 8 (2). 242-246.

51. Zadani A. H, Magaji P. K, Sarkiyayi S and Wurochekke A. U (2018). Antisnake venom activity of the aqueous and ethanolic extracts of Crinum jagus bulb. Asian Journal Research in Biochemistry 2(2): 1-9. 